\title{
Nipawin Provincial Park
}

\author{
By C. Stuart Francis, Torch River
}

This has been a very ordinary summer as far as ususual happenings are concerned. The weather has been much too wet all through July and early August, but now seems to have improved.

We have made three trips into the Nipawin Provincial Park since July lst. This is a very beautiful region with scores of lakes of various sizes, most of which contain several species of fish. Beautiful rollinghills surround the lakes. In some places the hillsides are so steep that you can throw a. stone into the water below from the top of a 150 or 200 foot hill. The forest is very varied and consists mostly of White and Black Spruce Jack and Banksian Pine, White Birch, Tamarack, Aspen Poplar, Balsam Poplar Balsam Fir, and in some places native Juniper and Box Elder. Pin Cherry, Chokecherry, Hazelnut and Highbush Cranberry are widspread throughout the region.

On August 3rd., while travelling through the Narrow Hills, the native Crocus was observed starting to

\section{Ringside Seat -}

(continued from page 22)

At such a brave dispaly, even a tractor tiller had to turn aside; first to the west side, then to the east. But the nest was never forsaken either time. I believe that when eggs are far on in incubation the birds are inuch more reluctant to fly then when they are still laying eggs.

A couple fo springs ago, while seeding near the buildings and also near Killdeer nest, sudden sleet. storm came blowing in froin the west. Ice pellets that stung the face sent me quickly heading for shelter. Wind that hurled dust and stubble tore in gusts across the field. Horses and cattle raced for the farm. And that night it snowed.

In the warm security of the house, that evening, I wondered if the Kildeer's nest would be thrown away. The answer came a couple of days later one sunny afternoon, when I noticed little fluffy balls on matchstick legs stumbling across the pasture. On rough ground they are easily caught bloom again in more than one spot, on stems two to three inches high, as in early spring. Possibly the very wet weather had something to do with this unusual occurance.

We have recently acquired a lot on which to build a cabin at Fishing Lakes, which is about the centre of the park area. This lake is surrounded with evergreen forests. The lake and the streams near by contain the following species of fish: Northern Pike, Pickeral, Perch, Whitefish, Tulibee and Trout. Out cabin will be situated on a high bank overlooking the lake. It will be about 25 feet above the water on the north-east corner of the lake, in a sheltered location.

In this park are also to be seen many stands of Mistletoe infested Jack Pine. These infested trees are known as "Witches Broom" on account of the odd broom-shaped form of growth of the branches of the entire tree. It reminds one more of a desert or Mexican landscrape, than of Northern Saskatchewan.

and these Kildeer babies were examined and cuddles a bit by the rest of the family and then returned to their anxious parents.

But how any bird could face those stinging pellets - cling to the ground in the wind and keep her eggs warm while an unreasonable snow covered the ground - well that is one of the intriguing things of nauter.

\section{Birding -- (continued from page 9)}

are careless nesters - most of the nests were just hollows in the sand, without lining or cover. Many single eggs lay in the edge of the water, apparently blown from their nests by the wind and waves. Other eggs found back on shore had evidently been eaten by crows. There were between twenty and thirty tern nests in four different locations along half a mile of shoreline. On July 16, some nests still contain eggs, but I banded 24 young which had exchanged their down for feathers and were old enough to swim. 